Selcuk Journal of Agriculture and Food Sciences

http://sjafs.selcuk.edu.tr/sjafs/index

Research Article

\section{SJAFS}

(2019) 33 (2), 114-120

e-ISSN: $2458-8377$

DOI:10.15316/SJAFS.2019.165

\title{
Agronomic Characteristics of Domestic and Abroad Originated Lentil Genotypes
}

\author{
Furkan ULUKUŞ ${ }^{1 *}$, Mustafa ÖNDER ${ }^{2}$ \\ ${ }^{1}$ Selçuk University, Graduate School of Natural Sciences, Department of Field Crops, Konya, Turkey \\ ${ }^{2}$ Selcuk University, Faculty of Agriculture, Department of Field Crops, Konya, Turkey
}

\begin{tabular}{l}
\hline ARTICLE INFO \\
\hline Article history: \\
Received date: 16.05 .2019 \\
Accepted date: 26.06 .2019 \\
\hline Edited by: \\
Ali KAHRAMAN; Selçuk University, \\
Turkey \\
Reviewed by: \\
Furkan ÇOBAN AtatürkUniversity, \\
Turkey \\
Hasan YILDIRIM; Republic of Turkey \\
Ministry of Agriculture and Forestry, \\
Turkey \\
\hline Keywords: \\
Breeding \\
Genetic resource \\
Introduction \\
Selection \\
Yield
\end{tabular}

\section{Introduction}

The rapid increase in the world population the decrease in production resources in line with this increase, the inability to use the technology in a favorable and efficient way, the negative environmental conditions and the regional domestic and foreign wars bring the problems of hunger and nutrition among the most important problems of humanity. To solve these problems, nutrient sources should be rich in properties such as energy, protein, vitamins and mineral substances and studies which increase nutrition, production and consumption of these foods should be carried out. In addition, due to the high costs of raising animal products, and because of the fact that their deterioration is quick and difficult to store and conserve, especially developing countries tend to plant herbal products which have higher amount of vegetable protein that can be stored for a longer period (Erkal 1981; Ceyhan et al 2014; Kahraman \& Önder 2018). Edible legumes both have a rich structure in terms of nutritional elements, amino acid contents and cheaper than animal products

\footnotetext{
*Corresponding author email: furkan_ulukus@hotmail.com
}

significantly increased the importance of these plants (McPhee et al 2012; Kahraman 2016).

Lentil plants which have an important place in edible seed legume in terms of their values and properties with $23-31 \%$ protein content, vitamins $\mathrm{A}, \mathrm{B}, \mathrm{C}$ and $\mathrm{K}$, as well as calories from soybeans (Akçin 1988; Ceyhan et al 2012). In addition, threonine and lycine amino acids, which are found in lentil plant proteins have an important role in human nutrition and these amino acids are almost closer to the values of beef (Aydoğan et al 2003). Lentil; high protein content and quality compared to cereals, $23-31 \%$ protein content, and rich in vitamins and minerals, and thereby improving amino acid balance when consumed alongside cereals (Baysal 1988; Pellet 1988; Özkaya et al 1998; Önder \& Kahraman 2008), it is a legume having an important place in eliminating people's hunger due to high fiber content (Trowell et al 1985; Önder \& Kahraman 2009).

Lentil is one of the oldest edible legumes that have an important place in both human and animal nutrition and its resistance has been known in agriculture dates back about 8000 years (Pellet 1988). The amount of nitrogen that is bound to soil symbiotically in edible seed leguminous plants varies according to plant spe- 
cies. This amount of lentils is about $8.4 \mathrm{~kg} \mathrm{da}^{-1}$ (Sepetoğlu 2002; Önder et al 2013). Lentil; as it increases soil fertility, it is preferred to have an important place in animal nutrition since it contains the least cellulose in the stalk and straw compared to other plants (Aydoğan et al 2003; Kahraman 2017).

While no many issues encountered of lentil varieties in Turkey, major problems are faced in the supply of seed to be used. In the production of lentils in Firat87, Çăğl, Yerli Kırmızı and Pul Mercimek a variety of indigenous local village varieties are common, and the seeds of these varieties are absent or inadequate. The producer produces his own seed with the varieties in his hand, and local varieties are used in these places under the absence of these varieties. It is known that local varieties show very large genetic variability and are very well adapted to the changing conditions of the region (Lázaro et al 2001; Ceyhan \& Kahraman, 2013; Kahraman et al 2015; Harmankaya et al 2016). However, due to their productivity stability, mechani-zation and other problems, production and yield values change continuously and sometimes become risk factors. Nevertheless, producers prefer these local varieties in small and especially stony areas. By evaluating the foreign origin varieties in terms of country and region, it is necessary to bring more modern varieties instead of old or local varieties, to create variability and to benefit from improved varieties with efficiency and other characteristics.

Lentils have an important part in human nutrition both in our country and in the world. The main purpose of this study is to determine the physiological characteristics (yield components) which have a positive effect on plant yield and to select the most efficient ones in domestic or foreign genotypes.

\section{Materials and Methods}

This research is a part of MSc thesis and was carried out in the farmer's fields in the Karapınar village of Acıgöl district of Nevşehir province, 220 indigenous and exotic lentils from Selcuk University, Faculty of Agriculture, and Field Crops Department were used as material. The origin of the 220 genotypes used in the experiment is shown in Table 3. As standard varieties; Fırat-87, Çağıl, Yerli Kırmızı, Pul Mercimek were used.

Table 1

Soil analysis of the experimental area.

\begin{tabular}{ll}
\hline Soil parameters & $0-20 \mathrm{~cm}$ \\
\hline Water at saturation $(\%)$ & 45 \\
Total salt $(\%)$ & 0.001 \\
Soil pH & 7.05 \\
Lime $(\%)$ & 1.58 \\
Plant available & 17.26 \\
phosphorus $\left(\mathrm{kg} \mathrm{da}^{-1}\right)$ & \\
Plant available & 78.35 \\
potassium $\left(\mathrm{kg} \mathrm{da}^{-1}\right)$ & \\
\hline
\end{tabular}

The study was planned as 5 blocks according to the Augmented trial design, and 4 standard cultivars of 44 genotypes +4 rows of each were made to each block.

The length of each row is $1 \mathrm{~m}$, the distance between the rows is $40 \mathrm{~cm}$, and the distance on the row is $5 \mathrm{~cm}$ ( 20 seeds per row) and the cultivation was by hand. In the light of this information, the length of our experiment $[44 \times 0.4 \mathrm{~m}]+[(4$ standard $\times 4$ rows $) \times 0.4 \mathrm{~m}]=$ $26 \mathrm{~m}$ length, $7 \mathrm{~m}$ wide area including space, the total area was planted to $182 \mathrm{~m}_{2}$ for the trial.

Regional climate data is presented in Table 2. While the average temperature was $17.30 \mathrm{C}$ for many years, it was $18.16^{\circ} \mathrm{C}$ in 2017 . When the average total rainfall was $31.04 \mathrm{~mm}$ according to the data of many years, it was determined as $27.58 \mathrm{~mm}$ in 2017 . When the relative humidity was $51.74 \%$ for many years, it was determined at $49.02 \%$ in 2017 .

In the analysis, it was determined that the soil structure was a sandy-loam and the soil reaction was neutral (pH: 7.05). The lime value was around $1.58 \%$ and very low range. In addition, it was found that there was no salt $(0.001 \%)$ problem, and phosphorus (17.26 kg da-1) and potassium (78.35 kg da-1) were generally sufficient in the area of the experimental field (Table 1).

In the field where the experiment was established, it was plowed with rock plows with the beginning of autumn rainfall, and in early spring (in March) the crowbar + harrow was drawn. On 10 April 2017, the cultivation of the experiment was done by hand while the soil was mellowness. $20 \mathrm{~kg}$ da-1 DAP (Diammonium Phosphate: $18 \% \mathrm{~N}, 46 \% \mathrm{P}$ ) fertilizer was applied in all the tested blocks.

The trial area was surrounded by wire around the external damage. In order to avoid confusion in the lines, each row and block is indicated by labels. Sprinkler irrigation system was established as an irrigation system and irrigation was done according to water demand and precipitation regime of the plant. According to the weed population, weed was taken by hand 3 times in April and May, and observation checks were conducted by hand while fighting regularly with weeds. When $90 \%$ of the plants in the block are ready for harvest (when the color of the leaves was yellow and the lower leaves begin to fall off, when the pods and seeds are hardened), the seeds of the next plants were harvested manually so that the seeds of each plant were packaged separately and then they were mixed after waiting without heating.

On the 220 lentil genotypes; the values of $50 \%$ flowering days, vegetation length, plant height, number of pods in the plant, 1000 seed weight, seed yield were evaluated. Observations and measurements were made according to TTSMM (Ministry of Food, Agriculture and Livestock Seed Registration and Certification Center Directorate) (TTSM 2018). 
Table 2

Climate data of the province of Nevşehir Acıgöl District of the vegetation period.

\begin{tabular}{|c|c|c|c|c|c|c|}
\hline \multirow[t]{2}{*}{ Months } & \multicolumn{2}{|c|}{ Monthly average temperature $\left({ }^{0} \mathrm{C}\right)$} & \multicolumn{2}{|c|}{ Monthly total rainfall (mm) } & \multicolumn{2}{|c|}{ Monthly average relative humidity $(\%)$} \\
\hline & $\begin{array}{l}\text { Long time } \\
\text { (30 years) }\end{array}$ & 2017 & $\begin{array}{l}\text { Long time } \\
\text { (30 years) }\end{array}$ & 2017 & $\begin{array}{l}\text { Long time } \\
\text { (30 years) }\end{array}$ & 2017 \\
\hline April & 10.1 & 10.1 & 50.1 & 38.9 & 57.8 & 50.3 \\
\hline May & 14.6 & 14.4 & 57.9 & 33.5 & 56.0 & 55.3 \\
\hline June & 18.6 & 19.3 & 33.9 & 32 & 51.7 & 53.0 \\
\hline July & 21.8 & 23.9 & 8.4 & 12 & 46.6 & 37.4 \\
\hline August & 21.4 & 23.1 & 4.9 & 21.5 & 46.6 & 49.1 \\
\hline Total Average & 17.3 & 18.16 & 155.2 & 137.9 & 51.74 & 49.02 \\
\hline
\end{tabular}

Table 3

The origin of lentil genotypes used in the research, local name.

\begin{tabular}{|c|c|c|c|c|c|}
\hline ACCESS NO & ORIGIN & LOCAL NAME & ACCESS NO & ORIGIN & LOCAL NAME \\
\hline PI 620882 & CHINA & LE-00-01 & PI 533693 & SPAIN & VERDINA \\
\hline PI 320936 & FSU & DAGHESTANICA & PI 612310 & PAKİSTAN & W6 19112 \\
\hline PI 320950 & ARMENIA & ASTARAKSKAJA MESTNAJA & PI 612307 & BULGARİA & $8,60 \mathrm{E}+287$ \\
\hline PI 345553 & FSU & IRANSKAJA 6 & PI 612282 & SYRİA & HAREM 10 \\
\hline PI 343029 & UKRAİNE & NEW MOOM & PI 612305 & BULGARİA & 84205001 \\
\hline PI 606604 & BULGARİA & NASLADA & PI 631395 & SYRİA & ALI DAYI \\
\hline PI 319366 & MEXİCO & LENTEJAS & PI 612300 & TURKEY & WJK94-T51 \\
\hline PI 612280 & SYRİA & EL-SUEYDA 8 & PI 638619 & SYRİA & GACHSARAN \\
\hline PI 636683 & ARMENİA & ARM 170 & PI 612284 & SYRİA & SAFEETA 12 \\
\hline PI 612287 & SYRİA & VAN WILSON 16 & PI 308608 & SYRIA & BALADI \\
\hline PI 612299 & TURKEY & WJK94-T50 & PI 308611 & SYRİA & NORTHERN RED \\
\hline PI612285 & SYRİA & HOMS 14 & PI 606587 & PAKISTAN & LENTİL \#2 \\
\hline PI 606603 & NEPAL & MASURO (DHEAL) & PI 490289 & FRANCE & MARIETIE \\
\hline PI 643448 & SYRİA & KEF & W6 27754 & USA & $1048-8 \mathrm{R}$ \\
\hline PI 312175 & MEXİCO & LENTEJA & PI 345640 & FSU & ZELENAYA AHUN. \\
\hline PI 636553 & TURKEY & MP-10 & PI 606637 & CZECHOSLOVAK & LENKA \\
\hline PI 635040 & SYRİA & OZBEK & PI 379368 & SERBİA & IVANKOVSKA \\
\hline PI 636685 & USA & ILL 9843 & PI 543069 & PAKİSTAN & MASOOR 9-6 \\
\hline PI 631396 & SYRİA & IDLİB-2 & PI 477290 & PAKİSTAN & \\
\hline PI 533691 & SPAİN & LENTEJA VERDINA & PI 606606 & BULGARİA & STONKA-1 \\
\hline PI 312176 & MEXİCO & LENTEJA & W6 27781 & USA & PARDINA \\
\hline PI 606607 & BULGARİA & STONKA-2 & PI 577239 & BULGARİA & STELA \\
\hline PI 477298 & PAKISTTAN & $9+6$ & PI 345631 & FSU & PENZENSKAYA 14 \\
\hline PI 636515 & BULGARİA & $\mathrm{N} 440$ & PI 308609 & SYRİA & HOMSI/KORDI \\
\hline PI 612286 & SYRIA & DOMMA 15 & PI 339265 & TURKEY & YERLİ KUQUK \\
\hline PI 320949 & FSU & TADJIKSKAJA 95 & PI 612312 & NEW ZEALAND & TITORE \\
\hline PI 343029 & FSU & PETROV'S JUBILEE & PI 486127 & USA & \\
\hline PI 636685 & USA & ILL 7502 & PI 577238 & BULGARİA & JANA \\
\hline PI 357225 & SERBİA & SVETI NIKOLSKA & PI 557499 & USA & PALOUSE \\
\hline PI 606589 & SPAIN & LENTEJA PARDINA DE LEON & PI 577237 & BULGARİA & NASLADA \\
\hline PI 606585 & BULGARİA & NASLADA & PI 564719 & USA & BENEWAH \\
\hline PI 357224 & MACEDONIA & LOKALNA EDRA & PI 298921 & ITALY & ALTAMURA \\
\hline PI 612281 & SYRİA & HURAN 9 & PI 477922 & USA & TEKOA \\
\hline PI 533692 & SPAIIN & CASTELLANA & PI 606643 & UKRAİNE & KROKHMAL \#6 \\
\hline PI 592998 & SYRİA & ILL 5588 & PI 379369 & SERBİA & VELESKA \\
\hline PI 320954 & HUNGARY & SLOVENIAN KRAYODA & PI 344077 & TURKEY & ILL 602 \\
\hline PI 606590 & SPAIIN & LEREN & PI 343026 & FSU & TADZIR'S 95 \\
\hline PI 606638 & $\begin{array}{l}\text { CZECHOSLOVA- } \\
\text { KİA }\end{array}$ & PLAJEVSKAJA & PI 612279 & SYRIA & EDLAB 7 \\
\hline PI 339286 & TURKEY & ALACA & PI 606646 & UKRAİNE & NARJADNAİA \\
\hline PI 634209 & USA & PENNELL & PI 345635 & ARMENİA & RISOVAYA \\
\hline PI 518261 & INDİA & MASOUR LENTİLS & PI 518733 & BRAZİL & CNPH 84- 123 \\
\hline PI 577236 & BULGARİA & OBRAZTZOV CHIFLIK 7 & PI 612274 & BULGARİA & SADOVO 1 \\
\hline PI 343023 & UKRAİNE & NATIONAL 03 & PI 565081 & SPAIN & SPANISH BROWN \\
\hline W6 27758 & USA & CDC ROBIN & PI 601750 & USA & LOLITA \\
\hline W6 27782 & USA & PENNELL & PI 345636 & FSU & STEPNAYA 244 \\
\hline PI 368646 & SERBİA & GRADSKA & & FRANCE & ANICIA \\
\hline PI 379370 & MACEDONİA & PRILEPSKA & PI 345637 & TAJIKISTAN & TADZHIKSKAYA 95 \\
\hline PI 606639 & GERMANY & STEPNAJA 244 & PI 619099 & USA & MASON \\
\hline PI 612275 & SYRİA & ALEPPO 1 & PI 577235 & BULGARİA & MIZIA \\
\hline PI 343027 & FSU & ASTARAR'S LOCAL & PI 368651 & SERBİA & BRODSKA \\
\hline W6 27756 & USA & $964 \mathrm{~A}-46$ & PI 298924 & ITALY & TIPO TURCHE NO. 2 \\
\hline PI 636687 & USA & ILL 9938 & PI 606640 & ALBANIA & 963 \\
\hline PI 606641 & SYRİA & ILL 5684 & PI 339275 & TURKEY & SULTANI \\
\hline PI 606658 & PAKISTAN & PAK 20 & PI 357227 & MACEDONİA & LOKALNA S. \\
\hline PI 533689 & SPAIN & CASTELLANA & PI 620880 & SYRIA & S114 \\
\hline
\end{tabular}


Table 3 (Continuation)

The origin of lentil genotypes used in the research, local name.

\begin{tabular}{|c|c|c|c|c|c|}
\hline PI 606648 & ITALY & MOUNTAİN LENTİL \#1 & PI 345638 & ARMENIA & TALINSKAYA 6 \\
\hline PI 311107 & GUATEMALA & LENTOJA & PI 477299 & PAKİSTAN & $18+10$ \\
\hline PI 494067 & CHİLE & & PI 476366 & FSU & TALLINSKAJA 6 \\
\hline PI 612309 & ALBANIA & VENDREZHA & PI 606586 & PAKİSTAN & LENTILL \#1 \\
\hline PI 368649 & SERBİA & SITNA & PI 370481 & SERBİA & EDRA \\
\hline PI 345625 & FSU & ILL 605 & PI 343025 & FSU & NOVOURENSK 3565 \\
\hline PI 606659 & CANADA & INDIAN HEAD & PI 560159 & USA & WH 2040 \\
\hline PI 533690 & SPAİN & PARDINA & PI 508091 & USA & EMERALD \\
\hline PI 612308 & NEW ZEALAND & W6 17279 & PI 476367 & FSU & PENZENSKO 14 \\
\hline PI 343022 & UKRAIINE & STEPPE 244 & PI 605356 & SYRİA & BARIMASUR-4 \\
\hline PI 655566 & TAJIKİSTAN & TJK2006:001 & W6 27780 & USA & MILESTONE \\
\hline PI 298923 & ITALY & TIPO TURCHE NO.1 & PI 368648 & SERBİA & SITNA \\
\hline PI 543070 & PAKİSTAN & MASSOOR 18-10 & PI 379372 & SERBİA & GRADECKA \\
\hline PI 547039 & USA & WA8649041 & PI 605355 & SYRİA & BARIMASUR-2 \\
\hline PI 612276 & SYRİA & ALEPPO 2 & PI 339267 & TURKEY & KIRMIZI \\
\hline PI 612301 & JORDAN & JORDAN 3 & PI 547038 & USA & WA8649085 \\
\hline PI 308610 & SYRIA & KURD & PI 345552 & FSU & DAGESTANSKAJA \\
\hline PI 368645 & SERBİA & SITNA & W6 27760 & USA & GIZA-9 \\
\hline PI 644221 & SYRİA & TESHALE & PI 636514 & BULGARİA & N377 \\
\hline PI 368650 & MONTENEGRO & PLASNICKA & PI 345625 & UKRAİNE & LUNA 09 \\
\hline PI 518732 & BRAZIL & CNPH 84-122 & PI 508090 & USA & BREWER \\
\hline PI 612278 & SYRİA & REEHA 6 & W6 27759 & USA & ESTON \\
\hline PI 612306 & BULGARİA & ZIMNA LESTA & PI 339292 & TURKEY & SIYAH \\
\hline PI 655571 & GEORGİA & 9092 & PI 486288 & FRANCE & DUPUY \\
\hline PI 606660 & SYRIA & FRENCH 3 & PI 635041 & SYRİA & KAFKAS \\
\hline PI 620879 & BULGARİA & NADEJDA & PI 620881 & SYRİA & $\mathrm{S} 119$ \\
\hline PI 339270 & TURKEY & AKCA MERCİMEĞİ & PI 320953 & GERMANY & SCHWARZE LINSE \\
\hline PI 606642 & RUSSIAN & PENZENSKAİA & PI 345628 & FSU & NOVAYA LUNA \\
\hline PI 577240 & RUSSİAN & TADJIKSKAYA 95 & PI 641205 & TAJIKİSTAN & TJK04:20-113 \\
\hline PI 643449 & SYRİA & HALA & PI 27767 & USA & ILL 8006 BM4 \\
\hline PI 368647 & MACEDONİA & DUKATINSKA & PI 606650 & SPAİN & SPANISH BROWN \\
\hline PI 339266 & TURKEY & YERLİ KUQUK & PI 343024 & FSU & $\begin{array}{l}\text { PETROV'S 4/105 } \\
\text { PETROVSKAYA }\end{array}$ \\
\hline PI 518731 & BRAZİL & CNPH 84-021 & PI 345634 & FSU & ZELENOZERNAYA \\
\hline PI 612311 & PAKISTAN & W6 19113 & PI 606649 & ITALY & $\begin{array}{l}\text { MOUNTAİN LENTİL } 2 \\
\text { PETROVSKAYA }\end{array}$ \\
\hline PI 515969 & ARGENTİNA & PRECOZ & PI 345633 & FSU & JUBILEINAYA \\
\hline PI 592997 & SYRİA & ILL 5582 & PI 477920 & USA & CHILEAN 78 \\
\hline PI 643450 & SYRİA & RACHAYYA & PI 345632 & FSU & PETROVSKAYA 50 \\
\hline PI 543068 & PAKİSTAN & MASOOR VM-3 & PI 636542 & TURKEY & $\begin{array}{c}\text { KAYI } 91 \\
\text { PETROVSKAJA }\end{array}$ \\
\hline PI 641202 & USA & ILL 9918 & PI 476368 & FSU & YUBILEJNAJA \\
\hline PI 606647 & ITALY & CASTELLUCCIOO LENTİL & PI 543067 & PAKİSTAN & MASOOR DL-6 \\
\hline PI 477923 & USA & BREWER & PI 606591 & IRAN & LINE (HC393) \\
\hline PI 643451 & SYRİA & ALEM TINA & PI 477300 & PAKİSTAN & $18+12$ \\
\hline PI 641201 & HUNGARY & B92-129 & PI 477921 & USA & REDCHIEF \\
\hline PI 643452 & SYRİA & ASSANO & PI 513253 & PAKİSTAN & MASSAR \\
\hline PI 561105 & TURKEY & TU86-16-07 & PI 606605 & RUSSİAN & TADJISKUYA \\
\hline PI 612303 & JORDAN & JORDAN 2 & PI 298922 & ITALY & TIPO CASTELLUCCIO \\
\hline PI 561087 & TURKEY & TU85-083-01 & PI 345627 & UKRAINNE & NARIADNAYA 03 \\
\hline PI 612302 & JORDAN & JORDAN 1 & PI 339263 & TURKEY & SULTANI \\
\hline PI 612277 & SYRİA & SULMİAH 5 & PI 302398 & JORDAN & ILL 486 \\
\hline PI 606661 & SYRIA & FRENCH 4 & PI 643453 & SYRİA & SALIANA \\
\hline PI 636684 & ARMENİA & ARM 417 & PI 476369 & FSU & PETROVSKAJA \\
\hline PI 547037 & USA & WA8649090 & PI 345630 & FSU & NOVOURENSKAYA \\
\hline PI 612283 & SYRİA & EL-GHAB 11 & PI 543920 & USA & CRIMSON \\
\hline PI 612304 & BULGARİA & NPO-2 & PI 345626 & UKRAİNE & $\begin{array}{c}\text { KRASNOGRADSKA- } \\
\text { YA } 460\end{array}$ \\
\hline PI 345629 & FSU & NOVOURENSKAYA 3565 & PI 606588 & TURKEY & TU86-16-02 \\
\hline PI 518734 & BRAZILL & CNPH $84-125$ & W6 27757 & USA & BREWER \\
\hline PI 631397 & SYRİA & MEYVECI 2001 & PI 634208 & USA & MERRİT \\
\hline PI 543066 & PAKISTAN & WKP-88-3 & & SERBİA & SITNA \\
\hline PI 357226 & SERBİA & LOKALNA SITNA & & SERBİA & GRADECKA \\
\hline
\end{tabular}

\section{Results and Discussion}

The results of the variance analysis of the standard varieties used in the study are given in table 4 and the lowest and highest values for these standard varieties and genotypes are given in Table 5. As seen in Table 4, variance analysis of standard varieties was statistically significant at $1 \%$ probability limit $(\mathrm{p}<0.01)$ in terms of all examined properties and it was determined that it was important at $5 \%$ probability limit $(\mathrm{p}<0.05)$ in terms of vegetation length.

In terms of grain yield, in terms of yield, standard varieties were obtained from Çağıl with $188.80 \mathrm{~kg} \mathrm{da}^{-1}$ and Pulse Lentil with $62.05 \mathrm{~kg} \mathrm{da}^{-1}$. In terms of geno- 
types used in the experiment, the highest seed yield was obtained from the genotype ASTA-RAKSKAJA MESTNAJA of $35.88 \mathrm{~g} /$ plant and the lowest seed yield was determined with genotype

TJK2006:001 of 0.19 g / plant. These results show that high yielding genotypes can be used to increase seed yield in future breeding studies. In the studies, seed yield between 75-258.3 kg / da (Alıc1 1997), 49.6$95.5 \mathrm{~kg} / \mathrm{da}$ (Kaçar \& Azkan 1997), between 156.5Table 4

Analysis of variance of the properties examined in the research

\begin{tabular}{lcccccc}
\hline $\begin{array}{l}\text { Source of } \\
\text { DF variation }\end{array}$ & Seed Yield & $\begin{array}{c}\text { Thousan of } \\
\text { seed weight }\end{array}$ & Plant height & $\begin{array}{c}\text { Number of } \\
\text { pods per plant }\end{array}$ & $\begin{array}{c}\text { Vegetation } \\
\text { length }\end{array}$ & $\begin{array}{c}\% 50 \text { Flower- } \\
\text { ing days }\end{array}$ \\
\hline Standard & 3 & $* *$ & $* *$ & $* *$ & $*$ & $* *$ \\
\hline
\end{tabular}

*: $\mathrm{p}<0.05 ; * *: \mathrm{p}<0.01$

In the same way, the highest weight of one thousand of seed $41.98 \mathrm{~g}$ with Pul Mercimek variety, 31.88 $\mathrm{g}$ with Çağıl standard varieties were determined. When the genotypes were examined, the highest weight of one thousand of seed was obtained from genotype MASON of $162.31 \mathrm{~g}$ and lowest from genotype $9+6$ of $12.92 \mathrm{~g}$. The highest standard varieties were been identified from genotypes of course seeds. This result showed that there are probably successful genotypes in increasing the weight of one thousand seeds in breeding studies. In the conducted studies, weight of one thousand seeds between 38-50 g (Russell 1994), 24.75$35.75 \mathrm{~g}$ (Şakar et al 1997), between 38.1-72.4 g (Kaçar \& Azkan 1997), 24.2-42.0 g (Türk \& Atikyilmaz 1998), 34.86-48.26 g (Karadavut et al 1999), 36.6-45.1 g (Bildirici \& Çiftçi 2001), 26.8-40.1 g (Sözen \& Karadavut 2017) changes have been indicated. These results are consistent with our result.

The highest plant height among the standard varieties was measured with Pul Mercimek variety with $33.02 \mathrm{~cm}$ and the lowest plant height with $27.23 \mathrm{~cm}$ in Çağıl variety. The highest plant height of the genotypes used in the experiment was $43.99 \mathrm{~cm}$ with the number of genotypes of BRODSKA, and the lowest plant height was obtained from the genotype with $17.68 \mathrm{~cm}$ with the number of genotypes of ILL 486. 30 genotypes were identified higher than the standard varieties with the highest plant size.

Hopefully, genotypes have been found to increase plant height. In the studies, the plant height between 10-45 cm (Solh \& Erskine 1984),28.7-33.9 cm (Erskine \& Witcombe 1984), between 21-41 cm (Swarup \& Lal 1987), 20.4-24.9 cm (Günel et al 1993), between 6.2-24.2 cm (Gupta et al 1996), 32-64

cm (Şakar et al 1997), between 19.9-27.9 cm (Kaçar \& Azkan 1997), 30.0- 38.7 cm (Türk \& Atikyilmaz 1998), 28.9-38.0 cm (Bozdemir \& Önder 2009) changes have been determined. According to these results, our results are similar.

Pul Mercimek with the lowest standard of varieties in the number of pods was 59.87, and the highest standard was 167.49 . In terms of genotypes, the highest number of pods in the plant was determined as STELA
$247.4 \mathrm{~kg} / \mathrm{da}$ (Türk \& Atikyilmaz 1998), 89.1 -252.9 $\mathrm{kg} / \mathrm{da}$ (Koç 2004) between 88.40-128.16 kg / da (Ölmez 2011), between 72.82-186.16 kg / da (Öktem 2016) and the highest seed yield in the studies between $258.8 \mathrm{~kg} / \mathrm{ha}$ (Bozdemir \& Önder 2009), $206.3 \mathrm{~kg} / \mathrm{da}$ (Biçer \& Şakar 2011) and $200.5 \mathrm{~kg} / \mathrm{da}$ (Köse et al 2017) was observed. According to these results, similarities and genotypes were found. genotype with 440.62/ plant and the lowest genotype of 9.21 with ILL 605 genotype number were identified. 94 genotypes have higher values than standard varieties. In the studies, the number of pods in the plant between 8.92-13.88 (Günel et al 1993), 11-91 (Gupta et al 1996), 8.7-15.1 (Kaçar \& Azkan 1997), 20.16 -33.90 (Karadavut et al 1999), 22.8 -44.3 units (Koç 2004) changes were observed and the highest unit of 66.95 (Çölkesen et al 2005) and 26.35 units (Biçer and Şakar 2011) were found. In our study, the number of pods in the plant was higher than the values in the other study. This shows that we can use these genotypes to increase the number of pods in breeding studies. In light of this information, these genotypes can be used in breeding studies to increase the number of pods.

Among the standard varieties, the shortest vegetation length was 96.3 days with Çağ 1 l, and the longest vegetation length was 105.6 days with local red varieties. It was found that the shortest vegetation length of the genotypes was 79.85 days with genotype PAK20 and the longest vegetation length was 120.85 days with genotype PETROVSKAYA ZELENOZERNAYA. The vegetation length of the 61 genotypes used in the experiment was shorter than the standards. These genotypes can be used to develop early varieties in breeding studies. Vegetation length value between 80-89 days (Günel et al 1993), 85-152 days (Whitehead et al 2000) and 102.9-107.8 days (Bozdemir \& Önder, 2009) were found.

Among the standard varieties, the shortest $50 \%$ flowering days were 62.2 days with Çağll variety and 72.2 days with Pul Mercimek varieties. The genotypes included the genotypes with the shortest number of $50 \%$ flowering days of 46.5 with $18+12$ genotypes, and the longest $50 \%$ flowering days of 82 with CNPH84125 and ZELENAYA AHUNSKAYA genotypes were found. In the studies between 55-61 (Solh and Erskine, 1984), 41.8-64.6 (Erskine 1990), 55-61 (Günel et al 1993), 87-143 (Gupta et al 1996), 45-80 (Whitehead et al 2000), and 65.1-72.0 days (Bozdemir \& Önder, 2009) changes were observed. Many of these studies are in parallel with our study. 
Table 5

Standard types and genotypes according to the characteristics discussed in the minimum-highest values and lsd values.

\begin{tabular}{lcccccc}
\hline Characteristics & $\begin{array}{c}\text { Seed yield }(\mathrm{g} \\
\left.\text { plant }^{-1}\right)\end{array}$ & $\begin{array}{c}\text { Thousand } \\
\text { seed } \\
\text { weight }(\mathrm{g})\end{array}$ & $\begin{array}{c}\text { Plant height } \\
(\mathrm{cm})\end{array}$ & $\begin{array}{c}\text { Number of } \\
\text { pods per plant }\end{array}$ & $\begin{array}{c}\text { Vegetation } \\
\text { length (days) }\end{array}$ & $\begin{array}{c}\text { \%50 flower- } \\
\text { ing days }\end{array}$ \\
\hline Min & 0.19 & 12.92 & 17.68 & 9.21 & 79.85 & 46.50 \\
Max. & 35.88 & 78.31 & 43.99 & 440.62 & 120.85 & 82.00 \\
Çağ1 & $188.80 \mathrm{a}$ & $31.88 \mathrm{~b}$ & $27.23 \mathrm{c}$ & $167.49 \mathrm{a}$ & $96.2 \mathrm{~b}$ & $62.2 \mathrm{~b}$ \\
Firat & $132.98 \mathrm{~b}$ & $36.98 \mathrm{ab}$ & $30.68 \mathrm{~b}$ & $135.91 \mathrm{a}$ & $100.2 \mathrm{a}$ & $69.2 \mathrm{a}$ \\
Pul Mer. & $62.05 \mathrm{c}$ & $41.98 \mathrm{a}$ & $33.02 \mathrm{a}$ & $59.87 \mathrm{~b}$ & $103.4 \mathrm{a}$ & $72.2 \mathrm{a}$ \\
Yerli Kır. & $147.62 \mathrm{~b}$ & $37.02 \mathrm{ab}$ & $29.48 \mathrm{bc}$ & $135.72 \mathrm{a}$ & $105.6 \mathrm{a}$ & $71.4 \mathrm{a}$ \\
LSD (0.05) & 16.26 & 5.76 & 1,61 & 46.87 & 6.50 & 3.97 \\
\hline
\end{tabular}

In accordance with these results, genotypes used in the experiment can be utilized in the development studies of varieties suitable for the conditions of our region, in terms of seed yield and important agricultural characteristics.

\section{References}

Akçin A (1988). Yemeklik Tane Baklagiller. Selçuk Üniversitesi Yayınları.

Alıcı S (1997). Harran Ovası koşullarında farklı mercimek (Lens culinaris Medic.) çeşitlerinin morfolojik ve tarımsal karakterlerinin belirlenmesi üzerine bir araştırma. Harran Üniversitesi. FBE Yüksek Lisans Tezi.

Aydoğan A, Aydın N, Karagöz A, Karagül V, Horan A, Gürbüz A (2003). İç Anadolu ve kuzey geçit bölgelerindeki yeşil mercimek (Lens culinaris Medic.) genetik kaynaklarının toplanması, karakterizasyonu ve ön değerlendirmesi. 5: 13-17.

Baysal A (1988). Türk mutfağında mercimek ve nohut yemekleri. Herkes için Mercimek Sempozyumu. 2930.

Biçer T, Şakar D (2011). Mercimek (Lens culinaris Medic.) hatlarının verim ve verim özellikleri yönünden değerlendirilmesi. Harran Tarım ve Gıda Bilimleri Dergisi. 15 (3): 21-27.

Bildirici N, Çiftçi V (2001). Van ekolojik koşullarında yüksek verimli kışlık mercimek çeşitlerinin ve tane verimi ile verim öğeleri arasındaki ilişkilerin belirlenmesi üzerine bir araştırma. Çukurova Üniversitesi Ziraat Fakültesi Dergisi. 16 (1): 67-72.

Bozdemir Ç, Önder M (2009). Yazlık yeşil mercimek (Lens Culinaris Medic.) genotiplerinin ankara ekolojik koşullarında verim ve bazı verim özelliklerinin belirlenmesi. Selçuk Tarım Bilimleri Dergisi. 23 (49): 1-9.

Ceyhan E, Kahraman A (2013). Genetic analysis of yield and some characters in peas. Legume Research. 36 (4): 273-279.

Ceyhan E, Harmankaya M, Kahraman A (2014). Combining ability and heterosis for concentration of mineral elements and protein in common bean (Phaseolus vulgaris L.). Turkish Journal of Agriculture and Forestry. 38: 581-590.
Ceyhan E, Kahraman A, Ateş M K, Karadaş S (2012). Stability analysis on seed yield and its components in pea. Bulg. J. Agric. Scie. 18 (6): 887-893.

Çölkesen M, Çokkızgın A, Turan B, Kayhan K (2005). Kahramanmaraş ve Şanlıurfa koşullarında değişik kışlık mercimek (Lens Culinaris Medic.) çeşitlerinde verim ve kalite özellikleri üzerine bir araştırma. GAP IV. Tarim Kongresi. 21-23.

Erkal S (1981). Mercimek üretiminin yoğun olduğu Gaziantep-Urfa illerinde işletme düzeyinde üretim maliyetleri ve üretim tekniğinin ekonomik yönden değerlendirilmesi ile pazarlanması üzerine araştırma. Atatürk Bahçe Kültürleri Araştırma Enstitüsü. (5): 59.

Erskine W, Witcombe J R (1984). Lentil germplasm catalog.

Erskine W (1990). Agronomy of lentil harvest mechanization. Lentil Harvest Mechanization Tra ining Workshop. Amman (Jordan). 12-21 May 1990.

Günel E, Yilmaz N, Erman M, Kulaz H (1993). Van ekolojik koşullarında mercimeğin (Lens culinaris Medic.) fenolojik ve morfolojik özellikleri üzerinde araştırmalar. Yüzüncü Yıl Üniversitesi Ziraat Fakültesi Dergisi. 3: 315-323.

Gupta A, Sinha M, Mani V, Dube S (1996). Classification and genetic diversity in lentil germplasm. Lens Newsletter. 23 (1/2): 10-14.

Harmankaya M, Ceyhan E, Çelik S A, Sert H, Kahraman A, Ozcan. (2016). Some chemical properties, mineral content and aminoacid com-position of cowpeas [Vigna sinensis (L.) Savi]. Quality Assurance and Safety of Crops \& Foods, 8 (1): 111-116.

Kaçar O, Azkan N (1997). Bursa ekolojik koşullarında yetiştirilebilecek mercimek çeşitlerinin belirlenmesi üzerine bir araştırma. Türkiye II. Tarla Bitkileri Kongresi. 22-25.

Kahraman A, Önder M (2018). Accumulation of heavy metals in dry beans sown on different dates. J. Elem. 23(1): 201-216. DOI: 10.5601/jelem.2017.22.2.1308.

Kahraman A (2016). Nutritional components and amino acids in lentil varieties. Selcuk Journal of Agriculture and Food Sciences. 30 (1): 34-38. 
Kahraman A (2017). Nutritional value and foliar fertilization in soybean. Journal of Elementolog. 22 (1):55-66.

Kahraman A, Harmankaya M, Ceyhan E (2015). Nutritional variation and drought tolerance in chickpeas (Cicer arietinum L.). Journal of Elementology. 20(2):331-341.

Karadavut U, Erdoğan C, Özdemir S, Geçit H (1999). Küçük daneli bazı yabancı mercimek hatlarının Amik Ovası koşullarında kışlık olarak yetiştirilmesi üzerine bir araştırma. 3: 15-18.

Koç M (2004). Diyarbakır koşullarında bazı kırmızı mercimek (Lens culinaris Medic.) çeşit ve hatlarında verim ve verimle ilgili özelliklerin saptanması üzerine bir araştırma. Çukurova Üniversitesi. Adana. $43 \mathrm{~s}$.

Köse Ö D E, Bozoğlu H, Mut Z (2017). Yozgat koşullarında yetiştirilen yeşil mercimek geno-tiplerinin verimine ekim sıklığının etkisi. KSÜ Doğa Bilimleri Dergisi. 20: 351-355.

Lázaro A, Ruiz M, de la Rosa L, Martín I (2001). Relationships between agro/morphological characters and climatic parameters in Spanish landraces of lentil (Lens culinaris Medic.). Genetic Resources Crop Evolution. 48 (3): 239-249.

Mcphee K E, Kahraman A, Önder M, Ceyhan E, Tashtemirov B (2012). Response of Chickpea genotypes to drought. World Academy of Science Engineering and Technology. 66: 475-480.

Öktem A G (2016). Şanlıurfa koşullarında yetiştirilen bazı kırmızı mercimek (Lens culinaris Medic.) genotiplerinin verim ve verim öğelerinin belirlenmesi. Nevşehir Bilim ve Teknoloji Dergisi. 5 (1): 27-34.

Ölmez Z (2011). Adıyaman koşullarında değişik mercimek (Lens culinaris Medıc.) çeşitlerinde verim ve verim unsurları üzerine bir araştırma.

Önder M, Kahraman A (2009). Antinutritional factors in food grain legumes. Science and Technology s. 40-44 (Sözlü Sunum). International Symposium on Sustainable Development. 9-10 Haziran 2009.

Önder M, Kahraman A (2008). Mercimek çeşitleri-nin tanelerinde bulunan mineraller arasındaki ilişkiler ve kalite üzerine etkileri. vol. 3, s. 102-109 (poster bildiri). Karadeniz Uluslararası Çevre Sempozyumu (BIES'08). 25 - 29 Ağustos 2008. Türkiye.
Önder M, Kahraman A, Ceyhan E (2013). Correlation and path analysis for yield and yield components in common bean genotypes (Phaseolus vulgaris L.). Ratar. Povrt. 50 (2): 14-19.

Özkaya B, Özkaya H, Eren N (1998). Değişik tarla bitkilerinden sonra ekilen bazı mercimek çeşitlerinin pişme kaliteleri ve kimyasal özellikleri verim bazı özellikler ve pișme kalitesi. Glda Teknolojisi Dergisi. 3 (6).

Pellet P (1988). İnsan beslenmesinde mercimek ve nohutun yeri. Herkes için Mercimek Sempozyumu. 29-30.

Russell A (1994). 'Rajah'lentil (Lens culinaris Medic.). New Zealand journal of crop horticultural science. 22 (4): 469-470.

Şakar D, Biçer T, Gül Ö, Alp A (1997). Güney Doğu Anadolu yerel mercimeklerinde bazı özellikler yönünden gözlemlenen varyasyonlar. Tarla Bitkileri Kongresi. 22-25.

Sepetoğlu H (2002). Yemeklik dane baklagiller. Ege Üniversitesi.

Solh M, Erskine W (1984). Genetic resources of lentils, In: Genetic Resources and Their Exploitation Chickpeas. Faba beans and Lentils. Eds: Springer. 205-224.

Sözen Ö, Karadavut U (2017). Bazı yeşil mercimek genotiplerinde dane verimi ve verim komponentleri arasındaki ilişkilerin belirlenmesi. Tarla Bitkileri Merkez Araştırma Enstitüsü Dergisi. 26(1): 104110.

Swarup I, Lal M (1987). Performance of bold-seeded lentils in Madhya Pradesh [Lens culinaris]. Lentil Experimental News Service.

Trowell H, Burkitt D, Heaton K (1985). Dietary fibre, fibredepleted foods and disease.

TTSM (2018). Ministry of food, agriculture and livestock seed registration and certification centerdirectorate. https://www.tarimorman.gov.tr/BUGEM/TTSM

Türk Z, Atikyılmaz N (1998). Diyarbakır ekolojik koşullarında yüksek verimli kırmızı mercimek çeşitlerinin belirlenmesi. Harran Üniversitesi Ziraat Fakültesi Dergisi. 3 (3-4): 67-72.

Whitehead S, Summerfield R, Muehlbauer F, Coyne C, Ellis R, Wheeler T (2000). Crop improvement and the accumulation and partitioning of biomass and nitrogen in lentil. Crop Science. 40 (1): 110-120. 